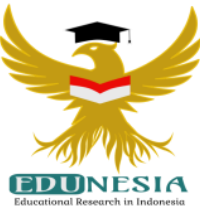

\title{
The Improvement of Civic Virtue through Civic Education in Higher Education in Forming Young Generation Communication Patterns
}

\author{
Lili Halimah'; Yayuk Hidayah2 Nufikha Ulfah'; ${ }^{3}$ Risti Aulia Ulfah ${ }^{4}$ \\ ${ }^{1}$ Department of Pancasila and Citizenship Education, STKIP Pasundan Cimahi, Indonesia \\ 2Department of Primary Education, Universitas Ahmad Dahlan, Indonesia \\ ${ }^{3}$ Department of Visual Communication Design, Institut Teknologi Sumatera, Indonesia \\ 4 Tarbiyah and Teacher Training, IAIN Ponorogo, Indonesia \\ ${ }^{2}$ Corresponding Email: yayuk.hidayah@pgsd.uad.ac.id, Phone Number : $0812 x x x x \times x \times x$
}

\section{Article History:}

Received: Mar 15, 2021

Revised: Apr 01, 2021

Accepted: Apr 06, 2021

Online First: Apr 07, 2021

Keywords:

Civic education, Civic

Virtue,

Young Generation.

Kata Kunci:

Civic Virtue,

Generasi Muda,

Pendidikan

Kewarganegaraan.
Abstract: This study purposed to describe the communication pattern of students at the University of Ahmad Dahlan Yogyakarta and described Civic Virtue implementation through civic education in higher education in terms of forming young generation communication patterns. This study employed a qualitative descriptive method. The subject of the study was five lecturers of civic education. Data were collected through interviews, observation, documentation, and focus group discussion (FGD). The data were analyzed by using Miles and Huberman's principles as data reduction, data display, and stating the conclusion. The result of the research showed that the students' pattern of communication at higher education was influenced by some factors were environment and knowledge factor. The fostering of Civic Virtue through civic education in higher education in forming young generation communication pattern has existed in the process of Civic Virtue fostering that involves democratic values, self-control, and prioritizing plurality interest. The Civic Virtue in the category civic disposition involves responsibility, self-discipline, human rights respect, willingness to hear, negotiating, and compromising. Besides, the Civic Virtue in the category of civic commitment involves a commitment to the implementation of democratic citizenship rights, responsibility for democratic citizenship, constitutionalism, and tendency to participate politically.

Abstrak: Tujuan penelitian adalah mendeskripsikan pola komunikasi pada mahasiswa dan pembinaan Civic Virtue melalui pendidikan kewarganegaraan di Perguruan Tinggi dalam membentuk pola komunikasi generasi muda. Penelitian ini menggunakan kualitatif deskriptif. Subjek penelitian adalah dosen pengampu MKI PKn yang berjumlah 5 orang. Pengambilan data melalui wawancara, observasi, dokumentasi, dan focus group discussion (FGD). Analisis data menggunakan model Miles dan Huberman berupa reduksi data, penyajian data, dan penarikan kesimpulan. Hasil penelitian menunjukan bahwa pola komunikasi pada mahasiswa di Perguruan Tinggi di pengaruhi oleh beberapa faktor, yaitu lingkungan, dan pengetahuan. Pembinaan Civic Virtue melalui pendidikan Kewarganegaraan di Perguruan Tinggi dalam membentuk pola komunikasi generasi muda terdapat beberapa skema yaitu pada proses pelaksaan pembelajaran pembinaan Civic Virtue meliputi nilai-nilai demokratis, Pengendalian diri, mengutamakan kepentingan bersama, Civic Virtue pada indikator civic dispotition meliputi tanggung jawab, disiplin diri, penghormatan terhadap HAM, kemauan mendengarkan, bernegosiasi, dan berkompromi, Civic Virtue pada indikator civic commitment meliputi komitmen terhadap pelaksanaan hak kewarganegaraan demokrasi, terhadap tanggung jawab kewarganegaraan demokrasi dan terhadap konstitusionalisme dan kecenderungan untuk berpartisipasi secara politik. 


\section{A. Introduction}

Communication is an activity that cannot be avoided. It is an integral part in the system and structure of human social life and society. Human communication can be seen in every aspect of daily life, like waking up in the morning until human will move back to sleep at night. Communication is essentially a process of delivering a message from the communicator to the communicant (recipient of the message) that can be done through a specific channel or delivered in person (Lunenburg, 2010).

Communication patterns that occur in an academic environment (like campus) can be divided into formal and non-formal communication. The atmosphere of formal communication can be exemplified as a lecturer that implement a learning in the classroom, while non-formal pattern is a communication that occurs outside of the classroom. The study against 6.601 chats between groups of students that were coded into one of three categories of social content interaction (social, task, or related technologies) results that student's chats on task was 55\%, 30\% of social, or 15\% related technology (Orvis et al, 2002). Besides, the patterns of communication in an academic environment is also based on the characteristics of each faculty. There is to be a very formal pattern and informal. However, the characteristics of each lecturer is not an obstacle to the emergence of a sense among faculty and student awards.

The previous study that investigated the behavior of communication in various fields of research that the cyber vigilantism in China by focusing on how the media has been adapted for online searches of personal information on social deviation to restore the morality of public, resulted that the identification of corrupt officials and the circulation of their personal data online strengthen the study on the abuse of power and to press the authorities towards greater accountability (Cheong \& Gong, 2010).

Furthermore, a research that focuses on the study of democracy realized that in implementing it in the classroom has produced that differences of opinion in a class discussion is implemented to produce a democratic supportive conditioning. The differences of opinion in the classroom is required to support the understanding of citizenship. Through the previous researches, the ability to communicate opinions through classroom can train a nuance of democracy (McMurray, 2007).

Meanwhile, the research on patterns of communication to the government via the internet raises interesting empirical and theoretical results. The study which emphasizes the role of communication in social conflicts generate social conflicts with the accompanied violence and it is best described as evidence of communication breakdowns (Hamijoyo, 2001). A research conducted in Surabaya on communication between the public and the government showed that the Public Information Group (KIM) played a role in two-side information that expanded the program and delivered complaints and suggestions from the public (Aji et al, 2018).

In facing the era of globalization that happened in 21st century, communication is essential and it demands good performance as today's social survival. Communication is part of the soft skills as mentioned in his article as "soft skills embedded into work area, visible through a good performance during the learning theory or practice, and the required soft skills such as communication (Hamidah, 2013). Hamidah conducted a research on students at Department of Culinary Arts State University of Yogyakarta. Her research was conducted to obtain a description of strength and weakness of nine soft skills of students. Based on the research, it was found that the strength of students soft skills towards communication was $49,90 \%$, meanwhile the weakness was $50,10 \%$. It could be concluded 
that communication became a part of students' soft skills (interpersonal skill) that was sharpened and improved through learning process.

Based on previous relevant researches, there are various forms of communication in the 21st century. Besides, the previous relevant researches has not conducted a research on fostering Civic Virtue through civic education in higher education to form young generation communication in the 21st century. Therefore, this study is expected to be able to complete the gaps in the research space to generate an idea of fostering Civic Virtue through civic education in higher education. This study is intended to focus on the communication patterns in the 21st century students and how is the education of Civic Virtue through civic education in higher education takes a role in shaping the young generation communication in the 21st century.

The purpose of this study is to describe the communication patterns in students and fostering Civic Virtue through civic education in higher education in shaping the young generation communication in the 21st century. The practical benefits of this study is to contribute ideas for the university to improve the efficiency of civic education in higher education to form young generation communication pattern. This study can be useful for further research that will examine the same theme.

\section{B. Method}

This study employed qualitative descriptive method which concentrate on descriptive data to produce a descriptive result (Moleong, 2002). The qualitative research was intended that the researchers could easily interpret about fostering Civic Virtue through civic education in higher education in forming young generation communication in the 21st century. This study was conducted in University of Ahmad Dahlan (UAD) Yogyakarta and College of Teacher Training and Education (STKIP) Pasundan Cimahi, West Java. The details of the object of study is as follows:

Table 1. Details of study's object

\begin{tabular}{lll}
\hline STKIP Pasundan, Cimahi & Class/Semester \\
\hline 1 & English Education & 3 \\
2 & Sport Education, Physics, and Rehabilitation & 3 \\
& \\
\hline \multicolumn{2}{l}{ Universitas Ahmad Dahlan (UAD) Yogyakarta } & Class/Semester \\
\hline 1 & Pharmacy & International/3 \\
2 & Mathematics & $\mathrm{A} / 3$ \\
3 & Mathematics & $\mathrm{B} / 3$ \\
\hline
\end{tabular}

The subjects of the study (researchers) were five lecturers of Civic Education. The data were collected by interview, observation, Focus Group Discussion (FGD) and documentation. 
Table 2. Indicator of Civic Virtue

\begin{tabular}{ll}
\hline \multicolumn{1}{c}{ Civic Virtue } & \multicolumn{1}{c}{ Key Words } \\
\hline & a) Responsibility \\
Civic Disposition & b) Self-discipline \\
& c) Human Rights respect \\
& d) Willing to hear, negotiate, and compromise. \\
& a) Commitment on the implementation of civic \\
Civic Commitment & b) Commitment on civic democratic responsibility. \\
& c) Commitment on Constitutionalism and tendency \\
& \\
&
\end{tabular}

The interview was conducted by involving several forms of question:

a) How do you show the attitude of responsibility and self-discipline?

b) How is your attitude when listening, negotiation, and compromise when doing the same work?

c) What is your opinion on the implementation of democracy in Indonesia?

d) What do you think about the constitution in Indonesia?

e) How is your attitude toward opinions and freedom of speech in public?

The observations carried out by observing behavior and activities of Civic Virtue coaching through civic education in higher education in forming young generation communication in the 21st century. The researchers made a list and record about activities within the study site. Focus Group Discussion was done by specifying topics related to teaching Civic Virtue through civic education in higher education to form young generation communication in the 21st century. Each team of Focus Group Discussion (FGD) two people in each. Documentation was intended to collect documents related to fostering Civic Virtue through civic education in higher education to form young generation communication in the 21st century. Finally, to analyze the data, this study employed Miles and Huberman's perspective that involved data reduction, data display, and concluding statement.

\section{Result and Discussion}

\section{Students' Communication Patterns}

In an effort to recognize the communication patterns to the students, the researchers firstly used data documents obtained through journals, research results, books and other relevant resources to complete the research findings and collaborate in the discussion. At the initial stage, the efforts of researchers in capturing the communication patterns of students is to ensure that this study is relevant to the theory of generation that emerges at present time. This is done, because the position of the students at this time is part of the $\mathrm{Z}$ generation, and they have been familiar with technology (Adam, 2017). In communication, the communication patterns by emphasizing openness is one of the communication pattern of generation Z (Husna, 2018).

Defining communication, the experts are trying to define communication from various perspectives. Jenis \& Kelly in Vardiansyah (2008) state that communication is the process to convey a message in the form of words to change the behavior of others. 
Meanwhile, Berelson \& Stainer in Vardiansyah (2008) also state that communication is the process of delivering information through symbols. Thus, there are some materials in the communication element, such as communicator, message, medium, and receiver.

In terms of communication patterns, there are three terms. First, one-side communication (the recipient of the message (communicant) only acts as a recipient of the message). Second, two-side communication (the exchange of functions between the receiver of the message and the recipient). Third, multi directional communication (Effendy, 1989).

Based on observation and interview against 3rd semester students at Department of Pharmacy (International class) University of Ahmad Dahlan Yogyakarta, there is a unique pattern of student communication. The tendency of a generation that is closed to the technology cannot be separated from their uniqueness. The feedback or circular of communication pattern can be seen at Instagram account ownership of class that is managed collectively (Cangara, 2006). The intention of Instagram account establishment is a "vent" media of what they have experienced in the classroom in order to get any feedback from the classmates. Therefore, an interpersonal communication as a systematic repetitive series, presents in this situation (Budyatna \& Ganiem, 2001).

The study on the communication pattern of students at USB YPKP on WhatsApp has resulted that the language used by the members of WhatsApp group is variety, such as Indonesian and regional languages like Sundanese, Javanese, Sumatran, Betawi, and Papua. In addition, the topics of conversation also varies. Although the dominant topic is academic topic, the students avoid to discuss and talk about political topic, because it is a sensitive case (Sidik \& Sanusi, 2018). In addition to using Instagram account, 3rd semester students at international class of Pharmacy also utilize Whatsapp group as communication tool that allows them to coordinate. Hence, communication by using various platforms is more instantaneous. Students recognize that their lives cannot be separated from digitalization, so they have adjusted to such this change.

The findings of further research is the use of the structure of the language used by students in conveying their message to communicate. Based on the results of interview against students of Mathematics (MIPA) class A and B can be found that the use of language that is straightforward and courteous in using Whatsapp group still exists. Meanwhile, in terms of communicating with their lecturer, students admit that they need to speak proportional language in accordance with the ethics of communication in academic environment.

The results of research on youth consumption practices in the use of technology has resulted that the fundamental motivation underlying the use of communication media is connectedness. The selection of communication technology depends on the structural nature of technology in improving social relationships (Behairy, Mukherjee, Ertimur, Venkatesh, \& Ertimu, 2006). Based on the interview, Focus Group Discussion (FGD) and documentation, has resulted that the students' communication patterns are affected by several things, include environment and knowledge.

Environment affects student communication patterns. The environment can be classified as culture and atmosphere of communication. Culture affects communication patterns can generally be identified by the use of intonation in communication. Based on the observation at University of Ahmad Dahlan Yogyakarta and STKIP Pasundan Cimahi, there are different uses of intonation in a communication between one student to other students. Nevertheless, there raised an awareness on students to be able to adjust according to their surrounding circumstances. A result of research on the effect of ethnic group membership 
and family communication environment for knowledge, dispositions, and political efficacy of adolescents to the United States has produced that teens use actual experience and representation by minority and majority culture in their socialization into politics (Austin \& Nelson, 1993). It is hypothesized that cultural individualism-collectivism, selfconstruction, and the values will have a separate effect on the use of individual communication styles in the context of low and high communication (Gudykunst et al., 1996).

Student communication patterns that is influenced by knowledge. It means that it is about the use of diction in absorption of the communication message. The result of research on the factors that influence the effectiveness of interpersonal communication of head of the Human Resources Agency at Bengkulu province results that interpersonal communication patterns are characterized by openness in various activities, support against employee, have a positive attitude towards employees and equality in the execution of tasks (Indah, 2018). The interview and Focus Group Discussion (FGD) on Math students (MIPA) at class A and $\mathrm{B}$ has resulted that the communication among students during the discussion proves that the use of language that is easily influenced has been applied by students. On the other hand, the personal communication patterns of the lecturer through Messenger application still need a coaching, especially in certain condition (like texting message without specifying a purpose and self-introduction. Conversely, the communication patterns of lecturers towards students is balanced. Based on the interview on Civic Education lecturers at University of Ahmad Dahlan Yogyakarta and STKIP Pasundan Cimahi, the communication between lecturer and student has been applied and it has constructed a pattern of mutual respect to gain an effective conversation. It can be well performed by the use of appropriate language and supported by verbal communication like eye-contact and hand-shaking.

The result of interview and Focus Group Discussion (FGD) on 3rd semester students at English Education STKIP Pasundan Cimahi based on a question related to the collaboration and cooperation between lecturer and student, has resulted that majority of students proves Civic Virtue as their willingness to create an effective situation in the collaboration and cooperation. The 3rd semester students of English Education at STKIP Pasundan Cimahi argue that in achieving an effective cooperation, they need to discard personal interest. They also realize that the presence of a leader in a cooperation becomes important supporting factor in creating an effective cooperation. The difference in perspectives is no longer a barrier in cooperation, but it is rather a positive thing that needs to be construed by its positive side. The students argue that different perspectives are important for them. Hence, the Civic Virtue of students at the category Civic Disposition by the emphasis on willingness in listening (hearing), negotiating, and compromising have been along with students personality.

Further Civic Virtue in the category of Civic Disposition is a self-discipline. Based on the observation towards students at University of Ahmad Dahlan Yogyakarta and STKIP Pasundan Cimahi, proves that the students have their ways in developing Civic Virtue in the category Civic Disposition within self-discipline. It is implemented by conducting various activities while focusing on these purposes. The students have an integrity in performing self-discipline by means of time discipline and social life discipline as nation. Their disciplines as nation are performed in their obedience towards the existing norm in their environment. A study on the theory of self-destiny determination (SDT) proves that the strong psychology supports human interactive and multidimensional character in any socio-cultural context (Sun, Norman, \& Abdourazakou, 2018). Civic Virtue in the category 
of Civic Disposition by means of Sef-discipline gives some ways of discipline are: time discipline and social life discipline. Civic Virtue has variety of meanings: bravery, patience, skill, and a nationality spirit (Syarifa, 2019). Thus, self-discipline in the improvement of Civic Virtue on students gives a description of Civic Disposition on students.

Furthermore, based on the observation, interview, and Focus Group Discussion (FGD) on 3rd semester students at Department of Sport Education, Physics, and Recreation STKIP Pasundan Cimahi has resulted that students have a responsibility in actualizing an awareness towards some particular tasks. Responsibility is an act of completing all tasks and being ready to sacrifice (Muhammad, 2000). The existence of class group gives a description that students are able to comprehend each of task. The description of Civic Disposition on students can be identified in some details of behavior and attitude actualization. Although Civic Virtue still needs any guidance and coaching, Civic Education is expected to be helpful in releasing to form a pattern of communication.

In detail, fostering Civic Virtue through Civic Education in Higher Education are as follows:

Table 3. Civic Virtue in higher education

No Kind of Civic Virtue Civic Virtue Fostering

1. The Process of Civic Education Learning

2. Civic Dispotition

3. Civic Commitment a) Democratic values

b) Self-control

c) Prioritizing togetherness

a) Responsibilty

b) Self-discipline

c) Human Rights respect

d) Willingness to hear, negotiate, and compromise

a) Commitment on the implementation of civic democratic rights.

b) Commitment on civic democratic responsibility.

c) Commitment on Constitutionalism and tendency to participate politically.

Development of Civic Virtue through Civic Education in Higher Education in Forming Young Generation Communication Patterns

The conception of Civic Virtue guidance through Civic Education in Higher Education in forming young generation's communication pattern in 21st century is based on Article 37 paragraph (1) and (2) of Law No. 20 of 2003 on National Education System that becomes one of underlying paradigm of Civic Education in Higher Education. Learning Civic Education means learning Indonesia (Nurwardan et al, 2016). Thus, the essence value of Indonesia still exists in the learning process of Civic Education. 
In the context of global Civic Education, Murdiono (2014) mentions some fundamental values in Civic Education that can be classified as deity, humanity, unity, citizenship, social equity, respect, peace, and independence. In analyzing Civic Education, there will be found many elements that are interesting to discuss. One of which is Civic Virtue. Civic Virtue is an act of nation to prioritize public interest above personal interest (Arif, 2017). Syarifa (2019) strengthens that Civic Virtue consists of Civic Disposition and Civic Commitment. Civic Disposition is a characteristics of nation, while Civic Commitment is a commitment of nation on democratic values underlying their lives.

The fostering of Civic Virtue through Civic Education in Higher Education in forming young generation communication pattern has a meaning that Civic Education in Higher Education becomes a platform in the process of fostering Civic Virtue. The result of survey in 2008 on the role of communication in socializing democratic citizenship towards teenagers in 12-17 years old and their parents has resulted that the participation in deliberative class activities has contributed civil activism within young generation personality. Specifically, the survey has highlighted online pathway of participation that merely focuses on news and political expression through internet technology (Lee et al, 2013). Based on the result of interview, Focus Group Discussion (FGD), and documentation, the researchers obtains a result that the fostering of Civic Virtue through Civic Education in Higher Education is available in the scheme process of learning that involves planning, implementation, and evaluation.

\section{Civic Education for Civic Virtue}

\section{Planning}

Planning is the process of determining how objectives, activities and results need to be achieved. The planning stage of learning is the initial stage that may affect the results achieved in learning. O.Hamalik (2009) states that a planning on learning as outlined in the RPS has a great function on the purpose of learning. There are three needs in the learning plan: resources plan, organizational learning plan, and implementation responsibilities plan.

The results of interview with Civic Education lecturers at University of Ahmad Dahlan Yogyakarta has proven that in the planning stages, Civic Education lecturer have set goals, methods, and achievements in the course. Lecturer plans learning by arranging RPS program begins with learning design to achieve the learning objectives that are systematically adjusted to higher education curriculum, and it is valid. RPS preparation of ICM on Civic Education conducted jointly with the ICM team Civic Education and RPS systematically arranged in accordance with the preparation of guidelines and format RPS. For ICM RPS Civics itself, there uniformity in its use.

\section{Implementation}

In the implementation of Civic Education learning, a lecturer tries to apply a learning model that can make the students active. The fostering of Civic Virtue through civic education on the process of learning is to use discussion as learning strategy. Based on observation in class A and B Department of Mathematics, there are some values that can be built up through the implemented strategy. These values are commitment and encouragement to take decisions and closeness in a group. The fostering of Civic Virtue in 
discussion can train students' self-control and sense of responsibility to the common interest in a group.

One of objectives in fostering Civic Virtue through Civics is to increase nationalism. Social circumstances along with potential conflict is a strong reason in teaching nationalism at school (Ben-Porath, 2007). Indonesia as a big country and has the potential for conflict, requires nationalism learning. Based on interview on 3rd semester international class at Department of Pharmacy, students admit that learning process of Civic Education can contribute a critical thinking and problem solving by prioritizing such discussion.

Based on interview and Focus Group Discussion (FGD) on Mathematic students at class A and B and international class at University of Ahmad Dahlan, has showed different results against the democratic values that form their attitudes prevalent as discussions take place. The democratic values indicated are appreciative and respectful attitude towards dissent and freedom of opinion based on the responsibility, to be fair in presenting their opinions, and not to interrupt when their friend are talking.

\section{Evaluation}

Assessment is an important component in education system. By the results of the assessment, the development and progress achieved by learners in education can be identified. Assessment is an important element in the learning process. The success of a teacher in educating students is not only proven by the high scores on cognitive ability, but also from the realization embodied the attitude of self-awareness on students themselves. The assessment of learning in higher education is set in the National Education Standards (NES), where the minimum criteria of learning in higher education across the jurisdiction contained in point (d) (Setiawan, 2013). The assessment standards that are further elaborated in Graduates Competency Standards is the minimum criteria of qualification the ability of graduates includes attitudes, knowledge, and skills stated in the Learning Outcomes (LO) formulation (Setiawan, 2013). Furthermore, article 19 mentions Assessment Standards of Learning is the minimum criteria of the assessment process and the learning outcomes of students in order to meet the LO graduates include: a) the principle of assessment, b) techniques and instruments, c) the mechanisms and procedures for assessment, d) the implementation of the assessment, e) reporting assessments, and f) graduation (Republik Indonesia Menristekdikti, 2015).

Based on the explanation above, the focus of assessment in this study refers to techniques and instruments that are used to assess the attitudes of students as a form of Civic Virtue, and it is implemented by using observation. The observations were carried out on the whole object of the research: students of International class A and B Department of Mathematics University of Ahmad Dahlan and students at English Education and Sport Education STKIP Pasundan.

\section{Conclusion}

The communication patterns of students in Higher Education is influenced by several factors, namely environment and knowledge. Fostering civic virtue through Civic Education in Higher Education in forming the communications of young generation is in the process of learning implementation of Citizenship Education that can foster civic virtue includes democratic values and self-control, focusing on common interests, civic disposition includes responsibility, self-discipline, respect for human rights, willingness to listen, 
negotiate and compromise, civic commitment includes the commitment to the implementation of democratic citizenship rights.

\section{Acknowledgment}

The researchers would like to thank the University of Ahmad Dahlan Yogyakarta and STKIP Pasundan Cimahi that have allowed researchers to carry out this research. We also would like to thank to all those who have been willing to be interviewed.

\section{References}

Adam, A. (2017). Good bye Millenial Generation, Welcome Generation Z (Selamat Tinggal Generasi Milenial, Selamat Datang Generasi Z). tirto.id.

Aji, G., Tsuroyya, \& Dewi, P. (2018). Bridging communication between public and government: a case study on kim surabaya. Journal of Physics: Conference Series, 953, 12194. https:/ / doi.org/10.1088/1742-6596/953/1/012194.

Arif, D. B. (2017). The improvement of civic virtue in Indonesia multicultural society: The role of civic education (Pengembangan kebajikan kewargaan (civic virtue) dalam masyarakat multikultural Indonesia: peran pendidikan kewarganegaraan). Journal Civics \& Social Studie, 1.

Austin, E. W., \& Nelson, C. L. (1993). Influences of ethnicity, family communication, and media on adolescents' socialization to U.S. politics. Journal of Broadcasting $\mathcal{E}$ Electronic Media, 37(4), 419-435. https:/ / doi.org/10.1080/08838159309364233.

Behairy, N., Mukherjee, S., Ertimur, B., Venkatesh, A., \& Ertimu, B. (2006). TechnologyBased Communication Patterns of Youth. In in NA - Advances in Consumer Research Volume 33, eds. Connie Pechmann and Linda Price, Duluth, MN : Association for Consumer Research (Vol. 33, hal. 304-305).

Ben-Porath, S. (2007). Civic virtue out of necessity: Patriotism and democratic education. Theory and Research in Education, 5(1), 41-59. https:// doi.org/10.1177/1477878507073608.

Budyatna, M., \& Ganiem, L. M. (2001). Theory of Interpersonal Communication (Teori Komunikasi Antarpribadi). Jakarta: Kencana.

Cangara, H. (2006). Introduction to Communcation Studies (Pengantar Ilmu Komunikasi). Jakarta: PT. Raja Grafindo Persada.

Cheong, P. H., \& Gong, J. (2010). Cyber vigilantism, transmedia collective intelligence, and civic participation. Chinese Journal of Communication, 3(4), 471-487. https:// doi.org/10.1080/17544750.2010.516580.

Effendy, O. U. (1989). Dictionary of Communicatio (Kamus Komunikasi. Bandung). Bandung: PT. Mandar Maju. 
Gudykunst, W. B., Matsumoto, Y., Ting-Toomey, S., Nishida, T., Kim, K., \& Heyman, S. (1996). The Influence of Cultural Individualism-Collectivism, Self Construals, and Individual Values on Communication Styles Across Cultures. Journal of Broadcasting E Electronic Media. https:/ / doi.org/10.1111/j.1468-2958.1996.tb00377.

Hamalik, O. (2009). The Planning of Teaching-based system (Perencanaan Pengajaran Berdasarkan Pendekatan Sistem). Jakarta: PT Bumi Aksara.

Hamidah, S. (2013). Soft skills profile of students of Catering Engineering Education (PTB), Faculty of Engineering, Yogyakarta State University (Profil soft skills mahasiswa pendidikan teknik boga Fakultas Teknik Universitas Negeri Yogyakarta),". Jurnal Pendidikan Vokasi, 2(3). https:// doi.org/10.21831/jpv.v2i3.1042.

Hamijoyo, S. S. (2001). Social Conflict with Violence and the role of communication role (Konflik sosial dengan tindak kekerasan dan peranan komunikasi). Jurnal Komunikasi MEDIATOR, 2(1). https://doi.org/10.29313/mediator.v2i1.696.

Husna, N. (2018). The Phenomenology of Generation Z Communication (Fenomenologi Komunikasi Generasi Z Z). Binus Univeristy. Diambil dari https://binus.ac.id/malang/2018/02/fenomenologi-komunikasi-generasi-z/.

Indah, D. P. (2018). The factor that influences interpersonal communication of Human Resource Chief at Bengkulu (Faktor yang mempengaruhi komunikasi interpesonal kepala Badan Sumber Daya Manusia provinsi Bengkulu). Journal of Administration and Educational Management (ALIGNMENT), 1(1), 48-55. https://doi.org/10.31539/alignment.v1i1.217.

Lee, N., Shah, D., \& Mcleod, J. (2013). Processes of Political Socialization A Communication Mediation Approach to Youth Civic Engagement. Communication Research, 40, 669697. https://doi.org/10.1177/0093650212436712.

Lunenburg, F. (2010). Communication: The Process, Barriers, and Improving Effectiveness. Schooling, 1. American Journal of Industrial and Business Management.

McMurray, A. J. (2007). The Role of Discussion and Dissent in Creating Civic Understanding. American Secondary Education, 36(1), 49-58. Diambil dari https://www.jstor.org/stable/41406098.

Moleong, L. J. (2002). Qualitative Research Methodology (Metode Penelitian Kualitatif). Bandung: Remaja Rosdakarya.

Muhammad, A. K. (2000). Indonesia's Civil Law (Hukum Perdata Indonesia). Bandung: citra Aditya Bakti.

Murdiono, M. (2014). Civic education to build young generation insights (Pendidikan kewarganegaraan untuk membangun wawasan global warga negara muda). 
Cakrawala Pendidikan, 3, 349-357.

Nurwardan, P., Saksama, H.Y., Winataputra, U.S., Budimansyah, D., Sapriya., Winarno, A., Festanto. (2016). Civic Education for Higher Education (Pendidikan Kewarganegaraan untuk Perguruan Tinggi). Jakarta: Direktorat Jenderal Pembelajaran dan Kemahasiswaan Kementerian Riset, Teknologi, dan Pendidikan Tinggi Republik Indonesia.

Orvis, K. L., Wisher, R. A., Bonk, C. J., \& Olson, T. M. (2002). Communication patterns during synchronous Web-based military training in problem solving. Computers in Human Behavior, 18(6), 783-795. https:// doi.org/10.1016/S0747-5632(02)00018-3.

Republik Indonesia Menristekdikti. (2015). The Rule of Higher Education Standard (Permenristekdikti tentang Standar Nasional Dikti). Jakarta: Kementerian Riset, Teknologi, dan Pendidikan Tinggi.

Setiawan, F. (2013). The ability of teacher in assessing learning through internalization of honesty on Civic Education) Kemampuan guru melakukan penilaian dalam pembelajaran melalui internalisasi nilai kejujuran pada pembelajaran Pendidikan Kewarganegaraan. JUPIIS, 5, 73-81.

Sidik, A. P., \& Sanusi, N. (2018). The Pattern of Students Communication in Social Media: Ethnography of Communication on Students at USB YPKB (Pola Komunikasi Mahasiswa Di Media Sosial: Studi Etnografi Komunikasi Pada Mahasiswa USB YPKP). In Conference: Seminar Nasional dan Dies Natalis 34 FISIP Unsoed "Media, Budaya, dan Politik di Era Milineal" Central Java, Indonesia, 2018.

Sun, Q., Norman, T. J., \& Abdourazakou, Y. (2018). Perceived value of interactive digital textbook and adaptive learning: Implications on student learning effectiveness. Journal of Education for Business, 93(7), 323-331. https://doi.org/10.1080/08832323.2018.1493422.

Syarifa, S. (2019). The Concept of Civic Virtue and Civic Education in Indonesia (Konsep Civic Virtue dan Pendidikan Kewarganegaraan di Indonesia).

Vardiansyah, D. (2008). Philosophy of Comunication Studies (Filsafat Ilmu Komunikasi: Suatu Pengantar). Jakarta: PT Indeks, 2008. 